E. A. Haddad, A. C. Giuberti

\title{
ECONOMIC IMPACTS OF NATURAL RESOURCES ON A REGIONAL ECONOMY: THE CASE OF THE PRE-SALT OIL DISCOVERIES IN ESPÍRITO SANTO, BRAZIL
}

The Brazilian government has recently confirmed the discovery of a huge oil and natural gas field in the pre-salt layer of the country's southeastern coast. It has been said that the oil fields can boost Brazil's oil production and turn the country into one of the largest oil producers in the world. The fields are spatially concentrated in the coastal areas of a few Brazilian states that may directly benefit from oil production. This paper uses an interregional computable general equilibrium model to assess the impacts of pre-salt on the economy of the State of Espírito Santo, a region already characterized by an economic base that is heavily reliant on natural resources. We focus our analysis on the structural economic impacts on the local economy.

${ }^{1}$ ○ Eduardo A. Haddad, Ana Carolina Giuberti. 2014. Text. 
Keywords: natural resources, impact analysis, inter-regional CGE model, Brazil, oil production, Dutch disease

\section{Introduction}

The State of Espírito Santo is best described as a small Brazilian state. It is responsible for only $2.3 \%$ of Brazilian gross domestic product (GDP) and is a home to $1.9 \%$ of the country's population. ${ }^{1}$ Its economy relies heavily on the natural-resources-based industry, the majority of whose products are exported. As Caçador and Grassi (2009) show, the commodity-based industry ${ }^{2}$ was responsible for $76.6 \%$ of the State's manufacturing value added and for $92.5 \%$ of the State's total exports in 2005. Production in the commodity-based industry is concentrated in a few big companies (Vale, Samarco, ArcelorMittal Tubarão, Aracruz Celulose, and Petrobras) that operate at an international scale. Vale, Samarco, ArcelorMittal Tubarão, Aracruz Celulose, and ArcelorMittal Belgo together were responsible for $77.4 \%$ of the State's exports.

The traditional industry ${ }^{3}$ is the second most important industry in the local economy, although it represented only $8.6 \%$ of the State's manufacturing value added in 2005 (Caçador and Grassi, 2009 , p. 463). Its importance lies in its geographic location: many industries, such as textile, clothing, and furniture are located upstate and are responsible for the creation of jobs and income in small municipalities. Moreover, the service sector related to foreign trade has an important role in the State's economy. In addition to being an exporter of commodities, the State can be considered the gateway for an important number of goods imported by trading firms. The establishment of these firms in the State of Espírito Santo was stimulated by the State Government through the Fundap ${ }^{4}$ system, which gives financial incentives to firms that import from the State's ports. In 2006 , these companies were responsible for $60.8 \%$ of the State's total imports and generated 30\% of the ICMS $^{5}$ tax revenue, by far the most impor-

\footnotetext{
${ }^{1}$ Estimates for 2007. Source: IBGE. Available at www.ipeadata. gov.br.

${ }^{2}$ The following sectors are considered part of the commodity industry: oil and gas extraction and related services, metal ore mining, pulp and paper manufacturing, basic metallurgy, manufacture of coke and petroleum refining, manufacture of nuclear fuel, ethanol production, and coal mining.

${ }^{3}$ By traditional industry we consider food and beverage production, textile industry, clothing and accessories manufacturing, leather manufacturing, luggage and footwear manufacturing, wood products manufacturing, and furniture manufacturing.

${ }^{4}$ Fund for the Development of Port Activities.

${ }^{5}$ Value added tax on goods and services.
}

tant State tax revenue (Caçador and Grassi, 2009, p. 458-459).

Although it is a small economy inside the Brazilian federation, the State of Espírito Santo was recently projected to the national economic scenario after the discovery of a huge oil and natural gas field in the pre-salt layer of the country's southeastern coast. The first discoveries of oil and natural gas in the pre-salt layer were announced in 2006, but it was not until 2008 that the volume of barrels was confirmed. The new reserves amount to 14 billion barrels of oil and natural gas; this, together with the 14 billion barrels of the post-salt layer already known, duplicates the Brazilian reserves. ${ }^{6}$ Of the 14 billion barrels, 3.5 billion barrels of oil of the light crude type are located on the coast of Espírito Santo. Besides that, the first oil well discovered is only 2.5 kilometers away from the FPSO JK (P-34) platform that, since 2006, has been extracting oil and natural gas from the post-salt layer of the State's coast. ${ }^{7}$ This fact has led to the anticipation of oil extraction of the pre-salt layer. Currently, Petrobras, the government-controlled national oil company, extracts around 15,000 barrels a day from this well and 15,000 more from the well located at Rio de Janeiro's coast. ${ }^{8}$ The company's goal to 2013 was to produce 100,000 barrels daily in the pre-salt layer of Espírito Santo's coast, with a predicted investment of R $\$ 10.3$ billion (nearly US\$ 5.7 billion) ${ }^{9}$ between 2009 and 2013. This goal represents an expressive increase in the output of the local oil and natural gas extraction sector; compared with the actual production of 140,000 barrels a day in the post-salt layer, the expected growth of the production is $70 \%$.

For the pre-salt layer as a whole, the goal of Petrobras to 2013 was to extract 219,000 barrels of oil and 7 million $\mathrm{m}^{3}$ of natural gas daily, with predicted investments of R\$ 28.9 billion (nearly US\$

\footnotetext{
${ }^{6}$ FOLHA ONLINE. Petrobras anuncia descoberta de reservas de petróleo em pré-sal do ES. 21 de novembro de 2008. Available at: <http://wwwl.folha.uol.com.br/folha/dinheiro/ ult91u470121.shtml>. Accessed 12/02/2009.

${ }^{7}$ AGÊNCIA ESTADO. Lula e Petrobras inauguram exploração do pré-sal nesta terça. 2 de setembro de 2008. Available at:<http://www.estadao.com.br/economia/not_eco234746,0. htm $>$ Accessed 12/02/2009.

${ }^{8}$ G1. Pré-sal vai produzir 1,8 milhão de barris por dia em 2020, diz Gabrielli. G1. Brasília, 08 de novembro de 2009. Available at:<http://g1.globo.com/Noticias/Economia_Negocios/ 0,,MUL1371103-9356,00.html> Accessed 12/02/2009.

${ }^{9}$ PETROBRAS (2009).
} 
16 billion) between 2009 and 2013. For 2020, the goal is 1.815 million barrels of oil and 40 million $\mathrm{m}^{3}$ of natural gas daily. If one considers that the Brazilian oil output in 2008 was 1.855 million barrels a day, one can see the magnitude of the presalt layer exploitation ${ }^{1}$.

The facts described above give rise to the question: Will this discovery of natural resources be a curse for the local economy? Although early economists stressed that natural resources would have a positive role in economic development, strong empirical evidence has shown a negative correlation between resource abundance and economic growth: resource-abundant countries tend to grow more slowly than resource-poor countries. Moreover, as the availability of natural resources per se should not mitigate economic growth, the literature on the "natural resource curse" has pointed out a number of explanations for these empirical results: the linkage theory, described in Gelb (1988); the "Dutch disease" effect, whose "core model" was presented by Corden and Neary (1982) and was also present in the model of Sachs and Warner (1999); the fluctuation of the terms of trade, with the implication for the volatility of the revenue associated with the natural resources (Auty, 2001); the crowding-out effect (Buffie 1993; Sachs and Warner, 2001); and rent-seeking effects (Torvik, 2002).

The methodology used to describe and analyze the natural resource curse varies across studies, and a great number of them use cross-country regressions or panel data. ${ }^{2}$ By far most studies concentrate on the country's economy as a whole, and only a few on regional economies. As far as we know only Papyrakis and Gerlagh (2007), Li and Polanski (2009), and Shao and Qi (2009) take on a regional approach, the former for the US states, and the latter two for Chinese provinces, although their focus was not exclusive on the Dutch disease mechanism or on the computable general equilibrium (CGE) methodology, on which we focus here. Papyrakis and Gerlagh (2007) used cross-state regressions to verify the effect of resource abundance on the per capita economic growth rate of 49 US states for which they had data. Their findings show that resource abundance can have a negative impact on growth through indirect channels such as investment levels, schooling rates, and openness. Li and Polanski (2009) studied the natural resource curse through the linkage theory. For them, the main eco-

\footnotetext{
${ }^{1}$ PETROBRAS (2009).

${ }^{2}$ The literature on the natural resource curse is quite extensive; we mention here a few examples of recent works in this line of investigation, which also review previous studies: Sachs and Warner, 1999, 2001; Papyrakis and Gerlagh 2004, 2007.
}

nomic explanation for the curse resides on the low intraregional linkages, both backward and forward linkages, of the natural resource sector with the supply chain. Using regional input-output data for China for 1997 and 2002, the authors verified the low linkage of this sector and the smaller growth of Chinese regions that based their growth on natural resources compared with other regions. Shao and Qi (2009) used cross-province panel data regression for provinces in Western China to analyze the effects of energy exploitation on growth. As a result, they found that energy exploitation has both direct and indirect negative effects on growth. The indirect effect hinders economic growth through science and technology innovation, human capital investment, and corruption.

The Dutch disease effect implies a structural change in the economy due to the boom in the natural resource sector. As the natural resource sector is a tradable sector, the inflow of revenue causes the real exchange rate to appreciate, which in turn dampens exports and the growth of the other tradable sectors, usually the more dynamic manufacturing sector or the agricultural sector in poor developing countries. Some authors (e.g., David, 1995) argue this cannot be called a disease, and consider it an adjustment to the new longrun equilibrium of the economy. It can be argued, however that this structural change is unwanted, because it reduces the capacity of the economy to maintain sustainable growth after the boom. Therefore, the Dutch disease mechanism implies general equilibrium effects in the economy, which makes CGE models appropriate tools to study these effects.

Thus, this paper makes a new contribution to the literature, combining the regional analysis with the CGE approach in evaluating the Dutch disease effect. It uses an interregional CGE model, called B-MARIA-ES (BMES), to assess the impacts of pre-salt on the economy of the State of Espírito Santo. We focus our analysis on the structural economic impacts, both in the short run and the medium run.

The remainder of this article is organized as follows. The next section describes the interregional CGE model used in this study. Section 3 presents the overall features of Espírito Santo's economy and of the oil and natural gas extraction sector. Section 4 discusses the results of the simulations, and the final section presents the conclusion of this study.

\section{The BMES Model}

To evaluate the effects of exploiting the pre-salt in Brazil under different economic en- 
vironments (closures), we departed from the B-MARIA-27 model, described in detail elsewhere (Haddad and Hewings, 2005). Its structure represents a further development of the Brazilian Multisectoral And Regional/Interregional Analysis Model (B-MARIA), the first fully operational interregional CGE model for Brazil. ${ }^{1}$ Its theoretical structure departs from the MONASHMRF Model (Peter et al., 1996), which represents one interregional framework in the ORANI suite of CGE models of the Australian economy. The interstate version of B-MARIA used in this research, the BMES model, contains over 480,000 equations, ${ }^{2}$ and it is designed for policy analysis in a comparative-static framework. The behavior of agents is modeled at the regional level, accommodating variations in the structure of regional economies. The model recognizes the economies of two Brazilian regions: the State of Espírito Santo and the rest of the country. Results are based on a bottom-up approach - national results are obtained from the aggregation of regional results. The model identifies 55 sectors in each region producing 110 commodities through a transformation process based on a constant elasticity of transformation (CET) specification. ${ }^{3}$ The model also recognizes one representative household in each region, regional governments and one federal government, and a single foreign consumer who trades with each region. Special groups of equations define government finances, accumulation relations, and regional labor markets. The mathematical structure of the suite of B-MARIA models is based on the MONASH-MRF Model for the Australian economy. It qualifies as a Johansen-type model in that the solutions are obtained by solving the system of linearized equations of the model. A typical result shows the percentage change in the set of endogenous variables after an exogenous change is carried out, compared with their values in the absence of such change, in a given environment. The schematic presentation of Johansen solutions for such models is standard in the literature. More details can be found in Dixon et al. (1992).

\footnotetext{
${ }^{1}$ The complete specification of the model is available in Haddad (1999).

2 There are 289 block equations and 346 block variables in the condensed model; the entire model contains 327 block equations and 397 block variables.

${ }^{3}$ The sectors/products are mapped into the three categories of Corden and Neary's core model: Booming sector - B (sector 3/ product 19), Lagging sector - L (sectors 1-39, but 3/products $1-89$, but 19 ), and Non-tradable sector (sectors $40-55 /$ products 90-110).
}

\subsection{CGE Core Module}

The basic structure of the CGE core module is very standard and comprises three main blocks of equations determining demand and supply relations, and market clearing conditions. In addition, various regional and national aggregates, such as aggregate employment, aggregate price level, and balance of trade, are defined here. Nested production functions and household demand functions are employed. For production, firms are assumed to use fixed proportion combinations of intermediate inputs and primary factors at the first level. At the second level, substitution is possible between domestically produced and imported intermediate inputs, on one hand, and between capital, labor, and land, on the other. At the third level, bundles of domestically produced inputs are formed as combinations of inputs from different regional sources. The modeling procedure adopted in BMES uses a constant elasticity of substitution (CES) specification at the lower levels to combine goods from different sources. Given the property of standard CES functions, non-constant returns are ruled out. One can modify assumptions on the parameter values to introduce external scale economies of the Marshallian type. Changes in the production functions of the manufacturing sectors in each region were implemented to incorporate non-constant returns to scale, a fundamental assumption for the analysis of integrated interregional systems. We kept the hierarchy of the nested CES structure of production, which is very convenient for the purpose of calibration (Bröcker, 1998), but we modified the hypotheses on parameter values, leading to a more general form. Non-constant returns to scale were introduced in the group of equations associated with primary factor demands within the nested structure of production. The sectoral demand for the primary factor composite (in region $r$ ), $y$, relates to the total output, $z$, in the following way: $y=a z^{\rho}$, with the technical coefficient $a$ and the parameter $\rho$ specific to sector $j$ in region $r$. This modeling procedure allows for the introduction of Marshallian agglomeration (external) economies, by exploring local properties of the CES function (Figure 1).

The treatment of the household demand structure is based on a nested CES/linear expenditure system (LES) preference function. Demand equations are derived from a utility maximization problem, whose solution follows hierarchical steps. The structure of household demand follows a nesting pattern that enables different elasticities of substitution to be used. At the bottom level, substitution occurs across different domes- 


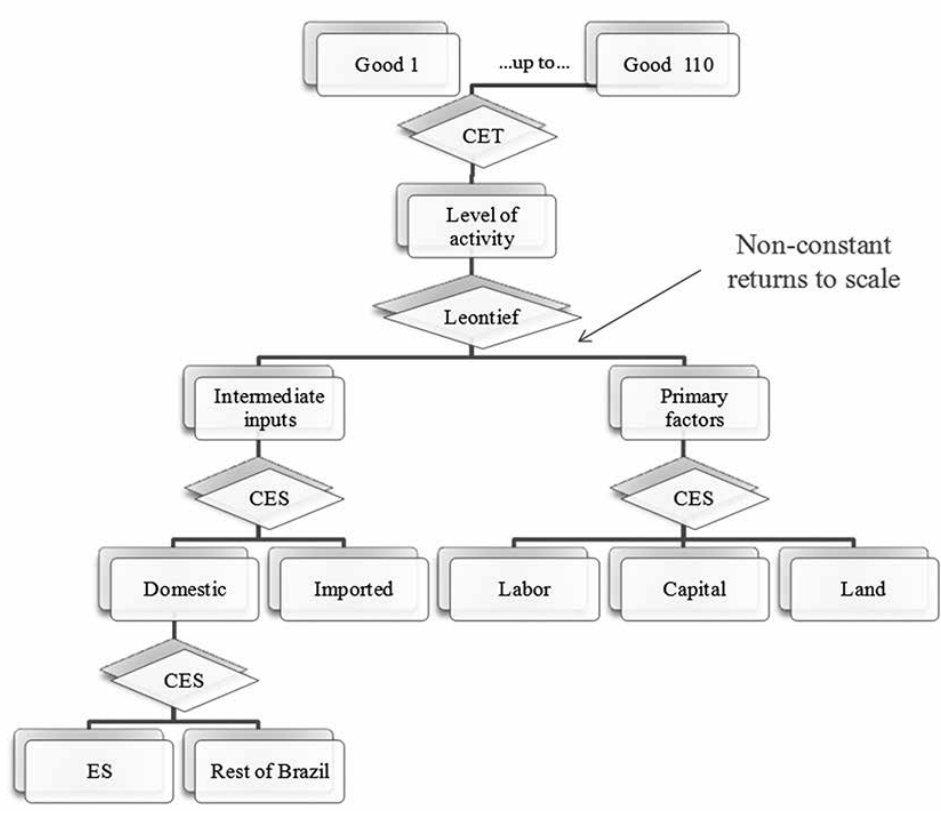

Fig. 1. Nested Structure of Production in the BMES model

definitions in the CGE core module include tax rates, basic and purchase prices of commodities, tax revenues, margins, components of real and nominal gross regional product (GRP)/ GDP, regional and national price indices, money wage settings, factor prices, and employment aggregates.

\subsection{Structural Database}

The CGE core database requires detailed sectoral and regional information about the Brazilian economy. National data (such as input-output tables, foreign trade, taxes, margins and tariffs) are available from the Brazilian Statistics Bureau (IBGE). At the regional level, a full set of statelevel accounts were developed at FIPE, University of Sao Paulo. These two sets of information were put together

tic sources of supply. Utility derived from the consumption of domestic composite goods is maximized. At the subsequent upper level, substitution occurs between domestic composite and imported goods.

Equations for other final demand for commodities include the specification of export demand and government demand. Exports face downward sloping demand curves, indicating a negative relationship with their prices in the world market. One feature presented in BMES refers to the government demand for public goods. The nature of the input-output data enables the isolation of the consumption of public goods by both the federal government and the regional governments. However, productive activities carried out by the public sector cannot be isolated from those by the private sector. Thus, government entrepreneurial behavior is dictated by the same cost minimization assumptions adopted by the private sector.

A unique feature embedded in the B-MARIA family of models is the explicit modeling of the transportation services and the costs of moving products based on origin-destination pairs. The model is calibrated taking into account the specific transportation structure cost of each commodity flow, providing spatial price differentiation, which indirectly addresses the issue related to regional transportation infrastructure efficiency. Such structure is physically constrained by the available transportation network, modeled in a geo-coded transportation module. ${ }^{1}$ Other

\footnotetext{
${ }^{1}$ See Haddad and Hewing (2005) for more details.
}

in a balanced interstate social accounting matrix, for the year 2004. ${ }^{2}$ Previous work in this task has been successfully implemented in interregional CGE models for Brazil (e.g., Haddad, 1999; Haddad and Hewings, 2005).

\subsection{Behavioral Parameters}

The benchmark figures for the regional elasticities of substitution were 3.0 for tradable goods and 2.0 for non-tradables. Parameter values for international trade elasticities were set at half the values of the corresponding regional trade elasticities. Substitution elasticity between primary factors was set to 0.5 . The parameters of scale economies were set to one in all sectors and regions, except for the core manufacturing sectors in the rest of the country, which were set to 0.8 . Elasticities of transformation in the CET specification were fixed at 0.05 for all sectors. The marginal budget shares in regional household consumption were calibrated from the social accounting matrix (SAM) data, assuming the average budget shares to be equal to the marginal budget shares. We set the export demand elasticities to -2.0. Finally, we assumed constant returns to bulk transportation, setting the parameter of scale economies in bulk transportation to one.

\subsection{Model Closures}

The full model contains 489,412 equations and 493,090 unknowns. Thus, to close the model, 3,678 variables have to be set exogenously. The

\footnotetext{
${ }^{2}$ This is the last year for which the full set information is available to calibrate the model.
} 
nominal exchange rate was set as the numéraire. To capture the effects of increases in oil production associated with the pre-salt, the simulations were carried out under two alternative closures, referring to different hypotheses on regional labor markets. There are no dynamics in the model. The simulations with the BMES model capture the effects associated with the static impact-effect question, i.e., given the structure of the economy, what-if questions can be addressed in a comparative-static framework. The closures differ in the way the equilibrating mechanisms in the labor markets are set. Structural changes are captured only through the evaluation of a re-allocation of resources.

In both closures, capital stocks are held fixed. In addition to the assumption of interindustry and interregional immobility of capital, closure 1 includes fixed regional population and labor supply, fixed regional wage differentials, and fixed national real wage. Regional employment is driven by the assumptions on wage rates, which indirectly determine regional unemployment rates. Labor is, thus, mobile only across sectors within the same region. On the demand side, investment expenditures are fixed exogenously - firms cannot reevaluate their investment decisions in the short run. Household consumption follows household disposable income, and real government consumption is fixed at both regional and central levels. Balance of payments has to adjust to changes in government deficit. Finally, preferences and technology variables are exogenous.

Closure 2 has the same set of assumptions as closure 1, except those for the labor markets. In closure 2, we also allow labor to move between regions. Aggregate employment is determined by population change, labor force participation rates, and the natural rate of unemployment. The distribution of the labor force across regions and sectors is fully determined endogenously. Labor is attracted to more competitive industries in more favored geographical areas, keeping regional wage differentials constant. Such a closure tries to mimic the equilibrating mechanisms in Corden and Neary's core model in the context of an integrated interregional system. By using two closures, with different degrees of interregional factor (labor) mobility, our goal is to assess the role of different hypotheses in driving the results of the Dutch disease type in a regional economy. While in closure 1 we have a more restricted set of hypotheses for labor mobility, in closure 2 the economic environment is closer to the more often discussed equilibrating mechanisms in Dutch disease models.

\section{Structural Setting}

The calibration of the model, i.e., the assignment of values to the relevant parameters and coefficients of the model to produce an initial solution, is based on the data files described above. By working with percentage changes rather than $a b-$ solute changes, the coefficients of the model are often readily interpretable cost and sales shares, and they can be derived from input-output tables. Together with values of substitution elasticities and some supplementary data on values of capital stocks, depreciation rates, demographic variables, and some other variables, the initial solution can be deduced.

In this section, the general structure of the absorption matrix is described in terms of summary indicators specifying agents' sales and purchases orientations, and output composition. An evaluation of the production linkages follows; based on the input-output flows, it provides a comparative analysis of the economic structure of the two regions. Traditional input-output multipliers are used in an attempt to uncover similarities and differences in the structure of the regional economies. We highlight some features of Espírito Santo's economy and of the state's oil and natural gas sector, based on the 2004 database used to calibrate the CGE model.

\subsection{The Economy of Espírito Santo}

Espírito Santo is a small Brazilian state, and, as pointed out in the introduction, its economy relies heavily on the natural-resources-based industry, the majority of whose products are exported. This reliance on natural resources can be traced back to the 1970s, when the military government implemented its Second National Development Plan and invested in industrial plants producing commodities in the State. Those investments encompassed the construction of major plants for pulp and cellulose (Aracruz Celulose), and steel and steel products (Samarco and CST, nowadays ArcelorMittal Tubarão), as well as the expansion of mining activities by Vale, at that time a stateowned enterprise.

As already pointed out, the State's GRP in 2007 was equivalent to $2.3 \%$ of Brazil's GDP and the State's population represented $1.9 \%$ of the country's population. Considering the 2004 database used in the calibration of the CGE model, those numbers were $2.0 \%$ and $1.8 \%$, respectively. It is important to note, however that for some sectors, the local output represented a larger share of the sectoral national output. For sectors such as manufacture of steel and steel products, iron ore pellets, other products of non-metallic minerals, and 
oil and natural gas extraction, the local output represented, respectively, $15.1 \%, 13.2 \%, 9.7 \%$, and $6.3 \%$ of the sector's national output.

The State's productive structure can be considered concentrated, with 12 out of the $55 \mathrm{sec}-$ tors presented in the model being responsible for $71.2 \%$ of the State's output. The three largest sectors are manufacture of steel and steel products, responsible $15.2 \%$ of the local output; transportation, whose output is equivalent to $7.9 \%$ of local output; and commerce, whose share is $7.1 \%$. The other nine sectors are food and beverages, public administration, construction, agriculture, oil and natural gas extraction, real estate services, other products of non-metallic minerals, iron ore pellets, and pulp and paper manufacturing.

Regarding the State's sales structure, $46.4 \%$ of the State's output is destined to the intermediate consumption, $21.6 \%$ is sold to households, $14.6 \%$ is exported, $9.9 \%$ is sold to regional governments and the federal government, and only $7.4 \%$ is destined to capital creation. From the output share that is destined to the intermediate consumption, only $18.1 \%$ is sold to local consumers, the rest (28.3\%) being sold to the rest of the country. This indicates a relatively low degree of intraregional linkages.

On the other hand, the data show a high degree of interregional dependence of the State. The State depends on the rest of the country to sell a considerable part of the State's output: if one adds the sales to the rest of the country of the intermediate consumption, capital creation, and household consumption, the result is that $38 \%$ of the local output is sold to the rest of the country. However, the country does not depend on the State: only $0.8 \%$ of its product is sold to Espírito Santo. This result is expected since Espírito Santo's economy is very small compared with the country's economy.

The main sectors of the economy export a large share of their products: the pulp and paper sector export $72.3 \%$ of its pulp output, the steel manufacturing and related products sector exports $70 \%$ of its pig iron and ferroalloys, and the iron ore pellets sector exports $65.5 \%$ of its output. Moreover, traditional sectors such as agriculture export most of their output. The main agricultural products exported are coffee, fish, poultry, and canned fruits and vegetables.

Regarding the cost and consumption structures of Espírito Santo, one can observe a certain balance in the aggregate. The cost structure is defined by (i) $40.0 \%$ of the intermediate consumption being supplied by the local production, (ii) $49.7 \%$ by the rest of the country's production, and (iii) $10.3 \%$ by imports. The household consumption structure is relatively similar, with a stronger presence of local output: (i) $47.9 \%$ of household consumption is supplied by the local production, (ii) $46.9 \%$ by the rest of the country's production, and (ii) $5.2 \%$ by imports.

\subsection{The Oil and Natural Gas Extraction Sector}

After almost shutting down in the first half of the 1990s, the oil and natural gas extraction sector in Espírito Santo experienced a rebirth following 1996 with the discovery of new reserves, most by Petrobras. As Caçador and Grassi (2009, p.461) show, between 1996 and 2006, the proven reserves of oil and natural gas grew $57.7 \%$ and $19 \%$, respectively while the national reserves as a whole grew $6.2 \%$ and $4.5 \%$, respectively. Thereafter, the State's production also increased in the same period, with the local production of oil increasing $21.3 \%$ and that of natural gas $13.2 \%$, both numbers superior to those of the national production (8.2\% and 6.8\%, respectively).

In 2004, the national production of the oil and natural gas sector was R \$ 51.68 billion (US\$ 17.67 billion); Espírito Santo's production was R $\$ 3.26$ billion (around US\$ 1.1 billion), which was equivalent to $6.3 \%$ of the national output. Measured in thousand barrels daily, the national production average was 1,539 and the local production average was 100 .

The indicators described above are based on interdependence ratios of the absorption matrix, which only measure the direct linkages among agents in the economy. A comparative analysis of regional economic structures can be carried out by considering production linkages among sectors through analysis of the intermediate inputs portion of the interregional input-output database. Both the direct and the indirect production linkage effects of the economy are captured based on the evaluation of the Leontief inverse matrix. The purpose remains the comparison of economic structures.

To examine the linkage structure of the local oil and natural gas extraction sector to the others sectors of Espírito Santo's economy and of the rest of the country's economy we rely on the analysis of its output multiplier (Table 1). The value of 1.894 is one of the highest for the State economy. The intraregional effect, however, is only 1.352 (71.4\% of the total), while the interregional effect is 0.542 (28.6\%).

For the rest of the country, the output multiplier of the oil and natural gas extraction sector is 1.858 , which can be divided between the intraregional effect of 1.829 and the interregional ef- 
Input-output multipliers: Intraregional and interregional output effects, Espírito

\begin{tabular}{|c|c|c|c|c|c|}
\hline \multirow{3}{*}{ Sectors } & \multirow{2}{*}{\multicolumn{3}{|c|}{$\begin{array}{c}\text { Output M ultipliers } \\
\text { ES }\end{array}$}} & \multirow{2}{*}{\multicolumn{2}{|c|}{$\begin{array}{c}\text { Shares } \\
\text { ES }\end{array}$}} \\
\hline & & & & & \\
\hline & Intra & Inter & Total & Intra & Inter \\
\hline 1 Agriculture, forestry, logging & 1.079 & 0.308 & 1.388 & 0.778 & 0.222 \\
\hline 2 Livestock and fishing & 1.155 & 0.424 & 1.579 & 0.732 & 0.268 \\
\hline 3 Oil and natural gas & 1.352 & 0.542 & 1.894 & 0.714 & 0.286 \\
\hline 4 Iron Ore & 1.273 & 0.533 & 1.806 & 0.705 & 0.295 \\
\hline 5 Other extractive industries & 1.223 & 0.566 & 1.789 & 0.684 & 0.316 \\
\hline 6 Food and Drink & 1.225 & 0.893 & 2.118 & 0.578 & 0.422 \\
\hline 7 Tobacco product & 1.115 & 0.923 & 2.038 & 0.547 & 0.453 \\
\hline 8 Textiles & 1.177 & 0.662 & 1.839 & 0.640 & 0.360 \\
\hline 9 Clothing and accessories & 1.188 & 0.541 & 1.729 & 0.687 & 0.313 \\
\hline 10 Leather goods and footwear & 1.183 & 0.845 & 2.027 & 0.583 & 0.417 \\
\hline 11 Wood products - exchusive mobile & 1.154 & 0.605 & 1.759 & 0.656 & 0.344 \\
\hline 12 Pulp and paper products & 1.197 & 0.621 & 1.818 & 0.658 & 0.342 \\
\hline 13 Newspapers, magazines, records & 1.123 & 0.524 & 1.647 & 0.682 & 0.318 \\
\hline 14 Petroleum refining and coking & 1.326 & 0.819 & 2.145 & 0.618 & 0.382 \\
\hline 15 Alcohol & 1.184 & 0.522 & 1.707 & 0.694 & 0.306 \\
\hline 16 Chemicals & 1.193 & 0.844 & 2.036 & 0.586 & 0.414 \\
\hline 17 Manufacture of resin and elastomers & 1.112 & 0.929 & 2.041 & 0.545 & 0.455 \\
\hline 18 Pharmaceutical products & 1.179 & 0.484 & 1.663 & 0.709 & 0.291 \\
\hline 19 Agrochemicals & 1.172 & 0.884 & 2.056 & 0.570 & 0.430 \\
\hline 20 Perfumery, hygiene and cleanliness & 1.175 & 0.666 & 1.841 & 0.638 & 0.362 \\
\hline 21 Paints, varnishes, enamels and lacquers & 1.225 & 0.851 & 2.076 & 0.590 & 0.410 \\
\hline 22 Various chemical products and preparations & 1.178 & 0.831 & 2.008 & 0.586 & 0.414 \\
\hline 23 Rubber and plastic & 1.139 & 0.864 & 2.003 & 0.569 & 0.431 \\
\hline 24 Cement & 1.209 & 0.407 & 1.616 & 0.748 & 0.252 \\
\hline 25 Other products of nonmetallic minerals & 1.240 & 0.509 & 1.750 & 0.709 & 0.291 \\
\hline 26 Manufacture of steel and steel products & 1.260 & 0.549 & 1.810 & 0.696 & 0.304 \\
\hline 27 Metallurgy of nonferrous metals & 1.219 & 0.589 & 1.807 & 0.674 & 0.326 \\
\hline 28 Metal products - except machinery and equipment & 1.225 & 0.510 & 1.734 & 0.706 & 0.294 \\
\hline 29 Machinery and equipment, inchding maintenance and repairs & 1.242 & 0.648 & 1.890 & 0.657 & 0.343 \\
\hline 30 Appliances & 1.254 & 0.661 & 1.915 & 0.655 & 0.345 \\
\hline 31 Office machines and computer equipment & 1.096 & 0.780 & 1.876 & 0.584 & 0.416 \\
\hline 32 Machinery, equipment and material & 1.190 & 0.637 & 1.827 & 0.651 & 0.349 \\
\hline 33 Electronic and communication equipment & 1.166 & 0.831 & 1.996 & 0.584 & 0.416 \\
\hline 34 Medical, hospital, measurement and optical apparatus / instruments & 1.119 & 0.397 & 1.515 & 0.738 & 0.262 \\
\hline 35 Cars, vans and utilities & 1.230 & 1.030 & 2.261 & 0.544 & 0.456 \\
\hline 36 Trucks and buses & 1.195 & 1.015 & 2.210 & 0.541 & 0.459 \\
\hline 37 Parts and accessories for motor vehicles & 1.206 & 0.786 & 1.992 & 0.605 & 0.395 \\
\hline 38 Other transportation equipment & 1.220 & 0.752 & 1.971 & 0.619 & 0.381 \\
\hline 39 Furniture and products of diverse industries & 1.148 & 0.605 & 1.753 & 0.655 & 0.345 \\
\hline 40 Electricity and gas, water, sewer and street cleaning & 1.246 & 0.548 & 1.793 & 0.695 & 0.305 \\
\hline 41 Construction & 1.207 & 0.357 & 1.564 & 0.772 & 0.228 \\
\hline 42 Commerce & 1.144 & 0.203 & 1.347 & 0.849 & 0.151 \\
\hline 43 Transport, storage and mailing & 1.179 & 0.475 & 1.654 & 0.713 & 0.287 \\
\hline 44 Information Services & 1.269 & 0.343 & 1.612 & 0.787 & 0.213 \\
\hline 45 Financial intermediation and insurance & 1.246 & 0.333 & 1.580 & 0.789 & 0.211 \\
\hline 46 Real estate services and rental & 1.037 & 0.041 & 1.077 & 0.962 & 0.038 \\
\hline 47 Maintenance and repair & 1.041 & 0.285 & 1.327 & 0.785 & 0.215 \\
\hline 48 Accommodation services and meals & 1.198 & 0.458 & 1.656 & 0.723 & 0.277 \\
\hline 49 Business services & 1.189 & 0.294 & 1.482 & 0.802 & 0.198 \\
\hline 50 Education mercantile & 1.238 & 0.305 & 1.543 & 0.802 & 0.198 \\
\hline 51 Health mercantile & 1.218 & 0.433 & 1.650 & 0.738 & 0.262 \\
\hline 52 Other services & 1.166 & 0.298 & 1.465 & 0.796 & 0.204 \\
\hline 53 Public education & 1.061 & 0.081 & 1.142 & 0.929 & 0.071 \\
\hline 54 Public health & 1.158 & 0.279 & 1.438 & 0.806 & 0.194 \\
\hline 55 Public administration and social security & 1.158 & 0.216 & 1.374 & 0.843 & 0.157 \\
\hline
\end{tabular}


Table 1

Santo and rest of the country

\begin{tabular}{|c|c|c|c|c|}
\hline \multicolumn{3}{|c|}{ Output Multipliers } & \multicolumn{2}{|c|}{ Shares } \\
\hline \multicolumn{3}{|c|}{ RBR } & \multicolumn{2}{|c|}{ RBR } \\
\hline Intra & Inter & Total & Intra & Inter \\
\hline 1.559 & 0.006 & 1.565 & 0.996 & 0.004 \\
\hline 1.758 & 0.007 & 1.765 & 0.996 & 0.004 \\
\hline 1.829 & 0.029 & 1.858 & 0.985 & 0.015 \\
\hline 1.675 & 0.015 & 1.690 & 0.991 & 0.009 \\
\hline 1.730 & 0.012 & 1.742 & 0.993 & 0.007 \\
\hline 2.185 & 0.012 & 2.197 & 0.995 & 0.005 \\
\hline 2.114 & 0.006 & 2.120 & 0.997 & 0.003 \\
\hline 1.932 & 0.007 & 1.939 & 0.996 & 0.004 \\
\hline 1.836 & 0.005 & 1.842 & 0.997 & 0.003 \\
\hline 2.111 & 0.008 & 2.119 & 0.996 & 0.004 \\
\hline 1.882 & 0.008 & 1.889 & 0.996 & 0.004 \\
\hline 1.881 & 0.029 & 1.910 & 0.985 & 0.015 \\
\hline 1.739 & 0.007 & 1.746 & 0.996 & 0.004 \\
\hline 2.112 & 0.047 & 2.159 & 0.978 & 0.022 \\
\hline 1.842 & 0.006 & 1.848 & 0.997 & 0.003 \\
\hline 2.071 & 0.017 & 2.088 & 0.992 & 0.008 \\
\hline 2.084 & 0.010 & 2.094 & 0.995 & 0.005 \\
\hline 1.741 & 0.006 & 1.747 & 0.996 & 0.004 \\
\hline 2.102 & 0.010 & 2.113 & 0.995 & 0.005 \\
\hline 1.916 & 0.008 & 1.924 & 0.996 & 0.004 \\
\hline 2.122 & 0.012 & 2.134 & 0.995 & 0.005 \\
\hline 2.056 & 0.009 & 2.065 & 0.996 & 0.004 \\
\hline 2.058 & 0.010 & 2.069 & 0.995 & 0.005 \\
\hline 1.707 & 0.018 & 1.725 & 0.990 & 0.010 \\
\hline 1.816 & 0.016 & 1.832 & 0.991 & 0.009 \\
\hline 1.832 & 0.043 & 1.875 & 0.977 & 0.023 \\
\hline 1.856 & 0.020 & 1.876 & 0.989 & 0.011 \\
\hline 1.792 & 0.050 & 1.843 & 0.973 & 0.027 \\
\hline 1.932 & 0.045 & 1.977 & 0.977 & 0.023 \\
\hline 1.948 & 0.046 & 1.994 & 0.977 & 0.023 \\
\hline 1.872 & 0.007 & 1.879 & 0.996 & 0.004 \\
\hline 1.886 & 0.023 & 1.908 & 0.988 & 0.012 \\
\hline 2.010 & 0.013 & 2.022 & 0.994 & 0.006 \\
\hline 1.604 & 0.012 & 1.616 & 0.993 & 0.007 \\
\hline 2.259 & 0.032 & 2.292 & 0.986 & 0.014 \\
\hline 2.216 & 0.026 & 2.242 & 0.988 & 0.012 \\
\hline 2.029 & 0.039 & 2.067 & 0.981 & 0.019 \\
\hline 1.964 & 0.039 & 2.003 & 0.981 & 0.019 \\
\hline 1.851 & 0.018 & 1.869 & 0.990 & 0.010 \\
\hline 1.616 & 0.007 & 1.623 & 0.996 & 0.004 \\
\hline 1.608 & 0.023 & 1.631 & 0.986 & 0.014 \\
\hline 1.394 & 0.004 & 1.398 & 0.997 & 0.003 \\
\hline 1.681 & 0.010 & 1.692 & 0.994 & 0.006 \\
\hline 1.619 & 0.003 & 1.622 & 0.998 & 0.002 \\
\hline 1.577 & 0.003 & 1.580 & 0.998 & 0.002 \\
\hline 1.079 & 0.001 & 1.080 & 0.999 & 0.001 \\
\hline 1.372 & 0.006 & 1.378 & 0.996 & 0.004 \\
\hline 1.748 & 0.008 & 1.755 & 0.996 & 0.004 \\
\hline 1.529 & 0.003 & 1.532 & 0.998 & 0.002 \\
\hline 1.550 & 0.005 & 1.555 & 0.997 & 0.003 \\
\hline 1.654 & 0.005 & 1.659 & 0.997 & 0.003 \\
\hline 1.507 & 0.005 & 1.512 & 0.997 & 0.003 \\
\hline 1.295 & 0.003 & 1.298 & 0.998 & 0.002 \\
\hline 1.536 & 0.004 & 1.539 & 0.998 & 0.002 \\
\hline 1.499 & 0.003 & 1.503 & 0.998 & 0.002 \\
\hline
\end{tabular}

fect of 0.029. Unlike in Espírito Santo, the expansion of the oil and natural gas extraction sector in the rest of the country has a very small interregional effect, whereas the expansion of this sector in Espírito Santo presents a considerably larger effect over the rest of the country's economy. This result originates from the linkages observed between this sector in Espírito Santo and the sectors located in the rest of the country. A closer look at the Leontief inverse reveals that, in the State economy, higher linkages can be found between the local production of oil and natural gas and the metal sector and machinery and equipments sector outside the State. Moreover, inside the local economy the oil and natural gas extraction sector has stronger linkages with service sectors, including transportation, services to companies, accommodation, real estate services, and information services, and, to a lesser degree, to the construction and the electricity sectors.

In the next section, BMES is used to evaluate the regional and sectoral impacts of recent presalt oil and natural gas discoveries in the Brazilian economy. The role played by the parameters and coefficients of the model, which are directly or indirectly derived from the structural indicators described above, is crucial for an understanding of the model's results.

\section{Simulation Results}

Petrobras' production goal to 2013 of 100,000 barrels daily in the pre-salt layer of Espírito Santo's coast represents an increase of around $100 \%$ in the regional oil output (compared with 2004, the benchmark year). Following Corden and Neary (1982), we model that in terms of a oncefor-all exogenous technical improvement in the oil and natural gas sector (the booming sector in the BMES model) that elevates its productivity proportionally to the expected increase in production. ${ }^{1}$ Thus, we impose the shock in the variables

\footnotetext{
${ }^{1}$ The justification for choosing such strategy for modeling the shock lies on the following bases: (i) As it follows traditional strategies used in the theoretical literature, it helps provide the basis for a heuristic validation of the results of the model. (ii) One alternative strategy would have been to set an exogenous increase in the capital stock of the oil-producing sector in Espírito Santo that would provide the desirable increase in oil production in the State. Pursuing this strategy in the context of this research has two major drawbacks: first, even though one can show it provides similar direct effects of an exogenous oncefor-all exogenous technical improvement in the specific capital factor, it would have been difficult to isolate the impacts of the operations phase, simulating the impacts of the increase in the oil production inside the region; second, given the quality of the data on sectoral capital stocks, we have decided to focus on the primary-factors returns variables to make sure we had the ap-
} 


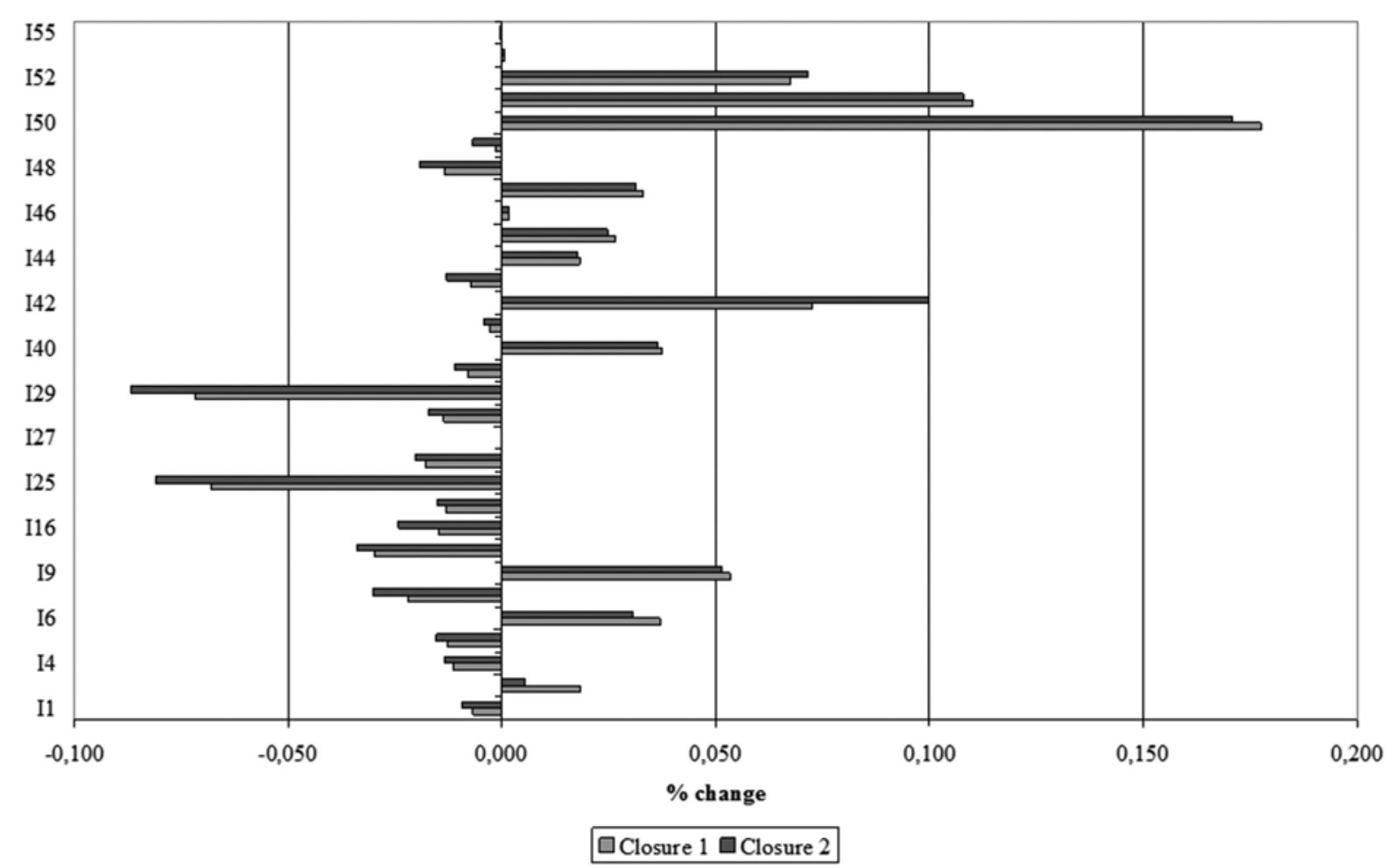

Fig. 2. Sectoral activity effects in the State of Espírito Santo

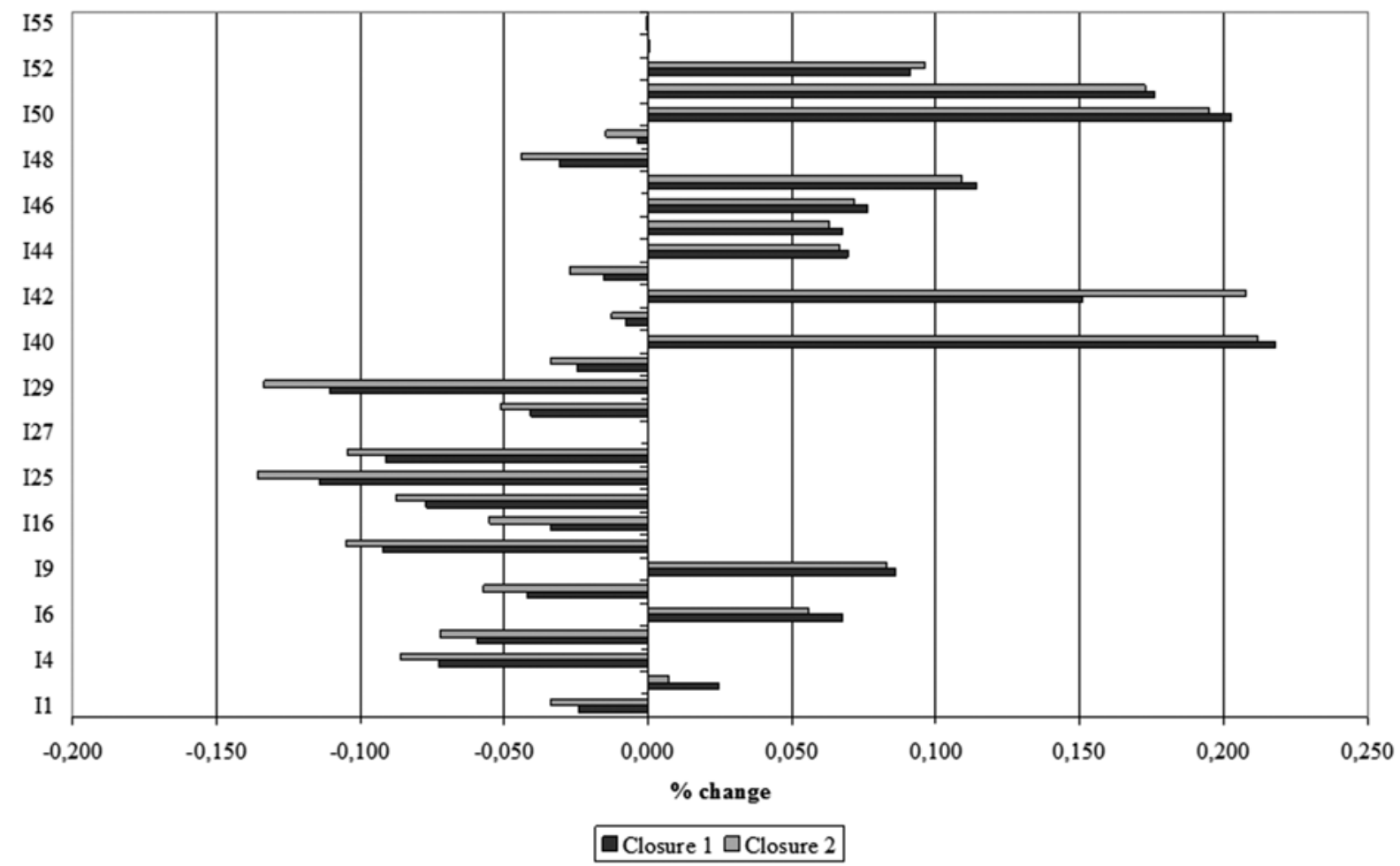

Fig. 3. Sectoral employment effects in the State of Espirito Santo

measuring "technical change" in BMES. The value adopted is - 50.0\% for Espírito Santo. That would

propriate metric. Finally, (iii) the strategy allows us to focus on the operations phase, even though we do not consider either oil production outside the region or the royalty channels to government expenditures. mean that $50 \%$ less of all inputs are needed to produce a given output of the oil and natural gas sector in Espírito Santo. The simulations were carried our using the software GEMPACK, using an Euler 2-4-6 procedure with 2 subintervals and extrapolation (Harrison and Pearson, 1996). 
Selected aggregate results

Table 2

\begin{tabular}{|c|c|c|c|c|c|c|}
\hline & \multicolumn{3}{|c|}{ Closure 1} & \multicolumn{3}{|c|}{ Closure 2} \\
\hline & $E S$ & $R B$ & Brazil & $E S$ & $R B$ & Brazil \\
\hline GRP & 7,1802 & 0,0031 & 0,1472 & 7,1819 & 0,0006 & 0,1448 \\
\hline Real household consumption & 0,1928 & 0,1070 & 0,1086 & 0,2436 & 0,1068 & 0,1094 \\
\hline Interrregional exports & 10,1973 & 0,0688 & 0,0000 & 10,1908 & 0,0849 & - \\
\hline Interregional imports & 0,0688 & 10,1972 & 0,0000 & 0,0849 & 10,1908 & - \\
\hline Intemational exports & 3,3720 & 0,0250 & 0,1316 & 3,3445 & 0,0119 & 0,1180 \\
\hline Intemational imports & $-0,2587$ & $-0,5332$ & $-0,5279$ & $-0,2413$ & $-0,5287$ & $-0,5232$ \\
\hline Relative prices (L) & 0,0780 & $-0,1030$ & $-0,0992$ & 0,0827 & $-0,0945$ & $-0,0908$ \\
\hline Relative prices (N) & 0,5529 & 0,4561 & 0,4578 & 0,6218 & 0,4819 & 0,4843 \\
\hline Domestic terms of trade & $-2,2464$ & 0,5123 & 0,0000 & $-2,2559$ & 0,5192 & - \\
\hline - without oil and gas in ES & 0,6183 & 0,5123 & 0,0000 & 0,6099 & 0,5192 & - \\
\hline Foreign terms of trade & $-1,4360$ & $-0,0567$ & $-0,1027$ & $-1,4372$ & $-0,0508$ & $-0,0970$ \\
\hline - without oil and gas in ES & 0,0240 & $-0,0567$ & $-0,0542$ & 0,0227 & $-0,0508$ & $-0,0485$ \\
\hline \multicolumn{7}{|l|}{ Activity level (aggregate): } \\
\hline Booming sector (B) & 105,7860 & 0,0000 & - & 105,7832 & 0,0000 & - \\
\hline Lagging sectors (L) & $-0,0063$ & $-0,0200$ & $-0,0197$ & $-0,0113$ & $-0,0243$ & $-0,0241$ \\
\hline Non-tradable sectors $(\mathrm{N})$ & 0,0221 & 0,0112 & 0,0114 & 0,0245 & 0,0093 & 0,0095 \\
\hline Realwage & $-0,0738$ & 0,0014 & - & $-0,0578$ & 0,0438 & 0,0419 \\
\hline CPI & 0,5126 & 0,4370 & 0,4384 & 0,5586 & 0,4562 & 0,4581 \\
\hline Unemployment rate & $-0,2779$ & 0,0008 & $-0,0045$ & - & - & - \\
\hline
\end{tabular}

Sectoral shares in regional factor income

\begin{tabular}{|c|c|c|c|c|c|c|c|c|c|}
\hline \multirow{3}{*}{ Wage income } & \multicolumn{3}{|c|}{ Benchmark } & \multicolumn{3}{|c|}{ Closure 1} & \multicolumn{3}{|c|}{ Closure 2} \\
\hline & $E S$ & $R B$ & Brazil & $E S$ & $R B$ & Brazil & $E S$ & $R B$ & Brazil \\
\hline & & & & & & & & & \\
\hline Lagging sectors (L) & 0,2849 & 0,2395 & 0,2403 & 0,2839 & 0,2394 & 0,2403 & 0,2839 & 0,2394 & 0,2403 \\
\hline Booming sector (B) & 0,0226 & 0,0064 & 0,0067 & 0,0254 & 0,0063 & 0,0067 & 0,0254 & 0,0063 & 0,0067 \\
\hline Nontradable sectors $(N)$ & 0,6925 & 0,7541 & 0,7529 & 0,6907 & 0,7543 & 0,7530 & 0,6907 & 0,7543 & 0,7531 \\
\hline Capital income & & & & & & & & & \\
\hline Lagging sectors (L) & 0,4293 & 0,2812 & 0,2846 & 0,3961 & 0,2814 & 0,2843 & 0,3957 & 0,2814 & 0,2842 \\
\hline Booming sector (B) & 0,0335 & 0,0138 & 0,0143 & 0,1025 & 0,0114 & 0,0136 & 0,1025 & 0,0114 & 0,0136 \\
\hline Nontradable sectors $(N)$ & 0,5372 & 0,7050 & 0,7011 & 0,5014 & 0,7072 & 0,7021 & 0,5018 & 0,7073 & 0,7022 \\
\hline Factor income & & & & & & & & & \\
\hline Lagging sectors (L) & 0,3749 & 0,2638 & 0,2662 & 0,3558 & 0,2640 & 0,2660 & 0,3555 & 0,2639 & 0,2660 \\
\hline Booming sector (B) & 0,0294 & 0,0107 & 0,0111 & 0,0748 & 0,0093 & 0,0107 & 0,0747 & 0,0092 & 0,0107 \\
\hline Nontradable sectors $(N)$ & 0,5957 & 0,7254 & 0,7226 & 0,5695 & 0,7268 & 0,7232 & 0,5698 & 0,7268 & 0,7233 \\
\hline
\end{tabular}

Tables 2 and 3 and Figures 2 and 3 present the results of the simulations; ${ }^{1}$ they show the percentage deviation from the base case (which is the situation without policy changes). The analysis concentrates on the effects on industrial activity and employment levels in the State of Espírito Santo,

\footnotetext{
${ }^{1}$ Results for the oil and natural gas sector are not shown, for presentation purposes.
}

and on some general macro and regional variables. We look at the results in the two closures described in section 2 . Overall, the results are qualitatively similar in both closures.

To better understand the sector results of the model, the structure of the economy must be analyzed. A close inspection of the benchmark database is necessary, conducted not only on the relationships in the input-output database, but also 
on the other relevant parameters of the model. Section 4 revealed some of the main structural features of the economy in the base year.

Industry activity results (Figure 2) show that, in general, non-tradable sectors benefit most from the increase in oil production in the pre-salt layer in Espírito Santo while tradable (lagging) sectors are the main losers. Explanations for a specific sector results should consider the structural and parametric aspects of the database. Sectors that present higher increases in their output tend to have a higher share of imports in their cost structure, and greater penetration in the local market. On the other hand, sectors that face higher interregional and foreign competition and present bigger exposure to non-local markets in their sales structure are more likely to be harmed by the policy change.

According to the model, industry employment levels expand/contract in the same direction as activity levels, as the capital stocks are fixed. Figure 3 shows the percentage changes in employment for each sector in Espírito Santo. Given the nature of the closure, which allows for producers to respond to exogenous shocks through changes in the employment level only, the figures reveal the supply responses from the model for a stimulus of the oil and natural gas sector. Thus, the changes tend to be similar in sign and relative magnitude to those for activity level.

It is evident that there is a movement towards de-industrialization of the regional economy, suggesting the potential Dutch disease effect that the State may face as production of oil in the pre-salt is fostered.

Table 2 summarizes the simulation results on some macro variables. The real GDP of Brazil is shown to increase by $0.145 \%$ to $0.147 \%$, with both regions positively affected. However, growth effects are highly concentrated in Espírito Santo, which experiences real GRP increases over 7.0\%, while the rest of the country's performance ranges from $0.001 \%$ to $0.003 \%$. Thus, regarding the regional distribution of income, the pre-salt oil production in Espírito Santo improves the regional relative position in the country.

The results reveal that the projected growth of Espírito Santo is heavily pushed by its export performance, in both domestic and international markets. Such export-led growth of Espírito Santo - more concentrated on sales to the rest of the country - relies on the trade performance of the oil and natural gas sector. As the sector produces an intermediate good not processed in the State of Espírito Santo (Brazilian oil refineries are located outside the State borders), the potentially most favored markets are other regions of the country. Thus, in the simulations, the share of oil and natural gas in the interregional exports from the State to the rest of the country goes from $10.7 \%$ in the benchmark to around $16 \%$ in both simulations. Moreover, the rest of the country tends to substitute away from imported oil as one of the domestic sources becomes more competitive.

The major difference noticed between the two closures is related to the spending effect, identified with the results for real household consumption. Significant spending effects appear, magnified in closure 2.

The main transmission mechanisms in the core theoretical model are also reflected in our results. In addition to the de-industrialization effect (reflecting both the spending and resource movement effects), described above and summarized in Table 2, which shows the decrease in the Lagging sectors (L) as opposed to an increase in the Nontradable sectors $(\mathrm{N})$, consistent relative price effects also show up. When changes in the relative prices of $\mathrm{L}$ are compared with $\mathrm{N}$ it is clear that prices of non-tradable goods rise relative to tradables. This acts in favor of an appreciation of real exchange rates, both domestic and foreign, as the results for terms of trade reveal: when the price of oil and natural gas is excluded from the calculations, prices of exports increase in relation to price of imports.

Finally, an increase in real rents of the Booming sector (B) at the expense of the specific factors in $\mathrm{L}$ (and also N) is also perceived, as factor shares in income in $\mathrm{B}$ rise from less than $3 \%$ in the benchmark to close to $7.5 \%$ in both simulations. Noteworthy is that, given the nature of the closure, the gains in factor share of the Booming sector is concentrated in capital income (Table 3).

\section{Final Remarks}

This paper has offered some pioneering efforts in looking at general equilibrium Dutch disease effects for a small regional economy in the context an integrated regional system. Modeling the regional economy of the State of Espírito Santo inserted in the national and international economies has proven relevant in addressing the potential impacts of oil production in the recently discovered pre-salt wells. The paper built on the BMES model, an interregional CGE model with non-constant returns and fully specified transportation costs.

The simulation strategy was to isolate the effects of the increase in oil production in the State of Espírito Santo, imposing a once-for-all exogenous technical improvement in the oil and natural 
gas sector in the State that elevates its productivity proportionally to the expected increase in production. By following traditional strategies used in the theoretical literature, the simulation strategy helped in providing the basis for a heuristic validation of the results of the model. Considering a similar setting of a national three-sector model, the results were in the expected direction as predicted by theoretical models. However, by incorporating more sectoral details and specific information on location for supply and demand, this exercise provided new insights for policy makers. As for the magnitudes of the impacts, they can be perceived in the context of a comparative static exercise, from which can be drawn a picture on potential gainers and losers from an increase in oil production in the State of Espírito Santo.

The results show that, from a regional perspective, one gains a better understanding of potential de-industrialization and real exchange rate appreciation effects not only from the links with the international economy, but also (and more importantly) from the links with other regions in the country, suggesting stronger dependence on national markets/suppliers.

As Haddad et al. (2002) have pointed out, the role of interregional trade in regional economies should not be relegated to a secondary place. One should consider interregional interactions to gain a better understanding of how the regional economies are affected, as for the smaller economies in Brazil, as in the case of Espírito Santo, the performance of the rest of the country plays a crucial role. Interstate trade might generate the potential for the propagation of feedback effects that, in quantitative terms, could be larger than the effects generated by international trade.

Inspection of the estimates of the interstate and international export coefficients for Espírito Santo in our database shows that interstate exports are 2.5 times higher than international exports. These estimates reveal, at first, the relevance of interstate trade in the regional economy.

One final aspect refers to the limitation of the results. Experience with the B-MARIA framework has suggested that interregional substitution is the key mechanism that drives the model's spatial results. In general, interregional linkages play an important role in the functioning of interregional CGE models. These linkages are driven by trade relations (commodity flows) and factor mobility (capital and labor migration).
In the first case, interregional trade flows should be incorporated in the model. Interregional input-output databases are required to calibrate the model, and regional trade elasticities play a crucial role in the adjustment process. One data-related problem that modelers frequently face is the lack of such trade elasticities at the regional level. The pocket rule, used in this paper, is to use international trade elasticities as benchmarks for "best guess" procedures. However, a recent study by Bilgic et al. (2002) tends to refute the hypothesis that international trade elasticities are lower bound for regional trade elasticities for comparable goods, an assumption widely accepted by CGE modelers. Their estimates of regional trade elasticities for the U.S. economy challenged the prevailing view and called the attention of modelers to proper estimation of key parameters. In this sense, in the absence of such estimates, extra effort should be undertaken to assess the robustness of the simulation results in relation to the set of elasticities used. This should be done in the sequence of this paper through proper estimation of regional trade elasticities and/or sensitivity analysis exercises.

In the second case, one should go one step further and look at different closure options. More specifically, it would be interesting to assess the impacts of pre-salt on the economy of the State of Espírito Santo in an economic environment in which capital flows are not restricted. As suggested by Corden and Neary (1982), allowing for capital mobility among sectors may lead to a more complicated transmission mechanism associated with the resource movement effect. The net effect may even be associated with an increase in the lagging sector, L. As one takes into account the further possibility of interregional capital movements, this issue becomes even more complex.

Finally, given the results of the paper, one could reach the conclusion that, for the State economy under consideration, understanding the future consequences associated with the booming of the oil sector should envisage not only traditional transmission mechanisms with the world economy, but also those related with the articulation of the local oil industry with domestic markets. In this context, more room for regional development policies might be advocated, through actions towards competitive strategies for enhancing intraregional linkages in the economy of Espírito Santo.

Acknowledgments. Financial support from the World Bank is gratefully acknowledged. Eduardo Haddad also acknowledges research grants from CNPq, Rede CLIMA and Fapesp. 


\section{References}

1. Agência Estado. (2008). Lula and Petrobras inaugurate the pre-salt exploration on Tuesday. 09.02.2008. Available at: http:// www.estadao.com.br/economia/not_eco234746,0.htm. (Date of access: 12.02.2009). (In Portuguese)

2. Auty R. M. (2001). Resource Abundance and Economic Development. Oxford: Oxford University Press.

3. Bandara J. (1991). An Investigation of "Dutch Disease" Economics with a Miniature CGE Model. Journal of Policy Modeling, $13,1,67-92$.

4. Benjamin N. et al. (1989). The Dutch disease in a developing country: oil reserves in Cameroon. Journal of Development Economics, 30, 71-92.

5. Bilgic A. et al (2002). Estimates of U.S. Regional Commodity Trade Elasticities. Journal of Regional Analysis and Policy, 32, 2.

6. Bresser-Pereira L. C. (2008). The Dutch disease and its neutralization: a Ricardian approach. Brazilian Journal of Political Economy, 28, 1 (109), 47-71.

7. Bröcker J. (1998). Operational Computable General Equilibrium Modeling. Annals of Regional Science, 32, 367-387.

8. Buffie E. F. (1993). Direct Foreign Investment, Crowding Out, and Underemployment in the Dualistic Economy, Oxford Economic Papers, 45, 639-667.

9. Caçador S. B.; Grassi R. A. (2009). Critical look on the recent performance of the capixaba Economy: An Analysis from the literature of regional development and innovation indicators. Revista Econômica do Nordeste, 40, 3, 453-480. (In Portuguese).

10. Corden W. M., Neary J. P. (1982). Booming Sector and De-Industrialization in a Small Open Economy. The Economic Journal, 92, 368, 852-848.

11. Corden W. M. (1984). Booming Sector and Dutch Disease Economics: Survey and Consolidation. Oxford Economic Papers, $36,3,359-380$.

12. Davis G. (1995). Learning to Love the Dutch Disease: Evidence from the Mineral Economies. World Development, 23, 10, 1765-1779.

13. Dixon P. B. et al (1992). Notes and Problems in Applied General Equilibrium Economics. Advanced Textbooks in Economics 32, Eds. C. J. Bliss and M. D. Intriligator, North-Holland, Amsterdam.

14. Folha Online (2009). Petrobras announces discovery of oil reserves in the pre-salt of ES. 11.21.2008. Available at: http:// www1.folha.uol.com.br/folha/dinheiro/ult91u470121.shtml. (Date of access: 12.02.2009). (in Portuguese).

15. G1. Pre-salt will produce 1.8 million barrels per day in 2020, says Gabrielli. G1.

16. Brasília, 11.08.2009. Available at: http://g1.globo.com/Noticias/Economia_Negocios/0,,MUL1371103-9356,00.html (Date of access: 12.02.2009). (In Portuguese).

17. Gelb A. H. (1988) Oil windfalls: blessing or curse? Published for The World Bank. Oxford University Press.

18. Haddad E. A. (1999) Regional inequality and structural changes: lessons from the Brazilian experience. Aldershot: Ashgate.

19. Haddad E. A. (2002). Regional Effects of Economic Integration: The Case of Brazil. Journal of Policy Modeling, 24, 453-482.

20. Haddad E. A. and Hewings G. J. D. (2005). Market Imperfections in a Spatial Economy: some experimental results. The Quarterly Review of Economics and Finance, 45, 476-496.

21. Harrison J.; Pearson K. (1996). An introduction to GEMPACK. GEMPACK user documentation GPD-1. Australia: IMPACT Project and KPSOFT Monash University.

22. Li J., Polenske K. (2009). The Curse of Natural Resources: Coal and Regional Economic Development in China. Mimeo, 2009.

23. Nkusu M. (2004). Aid and the Dutch Disease in Low-Income Countries: Informed Diagnoses for Prudent Prognoses. IMF Working Paper, 49.

24. Papyrakis E., Gerlagh R. (2004). The resource curse hypothesis and its transmission channels. Journal of Comparative Economics, 32, 181-193.

25. Papyrakis E., Gerlagh R. (2007). Resource abundance and economic growth in the United States. European Economic Review, 51, 1011-1039.

26. Peter M. W. et. al. (1996). “The Theoretical Structure Of MONASH-MRF”. Preliminary Working Paper no. OP-85, IMPACT Project, Monash University, Clayton, April.

27. Petrobras (2009). 2009-2013 Business Plan. January 26, 2009. Available at: <www.petrobras.com.br>. (Date of access: 11.27.2009). (In Portuguese).

28. Sachs J., Warner A. (1999) The big push, natural resource booms and growth. Journal of Development Economics, 59, 43-76.

29. Sachs J., Warner A. (2001). Natural resources and Economic Development: the curse of natural resources. European Economic Review, 45, 827-838.

30. Shao S., Qi Z. (2009). Energy exploitation and economic growth in Western China: An empirical analysis based on the resource curse hypothesis. Frontiers of Economics in China, 4, 1, 125-152.

31. Torvik R. (2002). Natural resource, rent seeking and welfare. Journal of Development Economics, 67, 2, 455-470.

\section{Information about the authors}

Eduardo Amaral Haddad (Sao Paulo, Brazil) - Ph.D., Full Professor at the Department of Economics, the University of Sao Paulo (Av. Prof. Luciano Gualberto, 908, FEA I, 05508-900, Cidade Universitária, São Paulo, SP — BRAZIL, e-mail: ehaddad@usp.br).

Ana Carolina Giuberti (Vitoria, Brazil) - Ph.D., Associate Professor at the Department of Economics, the Federal University of Espírito Santo (Av. Fernando Ferrari, 514, CCJE, 29075-910, Goiabeiras, Vitoria, ES - BRAZIL, e-mail: ana.giuberti@ufes.br). 